\title{
Exploration of Bian Embroidery's Traditional Skills and Industrialization Road
}

\author{
Huijuan Chang \\ Huanghe Science and Technology College \\ Zhengzhou, China
}

\begin{abstract}
China's embroidery has a long history, "Bian embroidery" as an embroidery form with Henan regional characteristics, has a long history, it is one of the most original and the oldest embroidery types. This article found innovative approaches from the artistic characteristics of Bian embroidery, expound in details from inheritance of the traditional implication essences, created and opened a personalized, diversified cultural regeneration road, it put forward the proposals and solutions for revitalization and development of Bian embroidery.
\end{abstract}

Keywords-Bian embroidery; traditional skills; culture regeneration

\section{THE DEVELOPMENT HISTORY OF BIAN EMBROIDERY}

Our embroidery has a very long history, there were records about the embroidery four thousand two hundred years ago. During the long time, embroidery derived a variety of species, Bian embroidery is one of them. But the name of Bian embroidery does not have a long history, it gradually developed after the founding of PRC. The birthplace of Bian embroidery is Kaifeng, known as Bian, short for Bian liang, so Kaifeng embroidery called Bian embroidery.

With dynasty changes, development of Bian Embroidery art continues. It was known for its exquisite skill, fine stitches, rigorous design pattern, elegant style and beautiful color. It was well-known throughout the country as early as Song Dynasty. Due to Jinbing's invasion, Song imperial household moved to south area, the war happened along with the flood, embroidery was failing into the lowest valley with the destruction of Northern Song Dynasty. But it was deeply rooted in the Central Plains, especially embroidery skills in the land of Kaifeng still widely spread in folk, its exquisite skills were inherited and admired by the future generations. With the changing times, Bian embroidery also boldly breaks the old, and choose the subject of Western-style paintings, decorative paintings, large murals and portraits. Introduce Western painting into the traditional Chinese embroidery was an outstanding pioneering work for embroidery skills, Bian embroidery colored and draw with thread which was the new technology and also the most difficult part in Bian embroidery. New crewel embroidery stitch called Luan Zhenxiu emerged that expresses light and shadow effects. It uses routine and disorderly stitches to express brushwork of paintings and the delicate relationship between light and shadow vividly. It is the perfect combination of two cultures, two civilizations, two ideological systems and a perfect combination with two different observation methods and performance methods. In the selection of raw materials it also committed the innovation, use the linen, wool fabric as the base material, emphasizing the contrast with embroidered face in order to make embroidery more vivid.

In January 2007, Kaifeng Bian embroidery Industry Association was formally established, her birth wishes to gather together the people in Bian embroidery industry to make Kaifeng Bian embroidery more systematic, standardized, and lay a good foundation for the Kaifeng Bian embroidery to the world .In 2007 Bian embroidery craft was selected in the first batch of Henan provincial intangible cultural heritage protection list.In 2008 the State Council included Bian embroidery craft in the national intangible cultural heritage protection list, and it has participated in the National Intangible Cultural Heritage Exhibition for many times.

\section{BIAN EMBROIDERY UNIQUE FEATURE RESEARCH}

For thousands of years, embroidery as a unique skill also rises and falls with the vicissitude of literature and art. Open the growth history of Bian embroidery, the Bian embroidery can be said as the crystallization of the humanities, is was a gallery of Chinese Painting and Calligraphy. Bian embroidery has combined with calligraphy and painting in Northern Song Dynasty, the topics include landscapes, flowers and birds, pavilion, figures and others. After the liberation, Bian embroidery inherited the excellent tradition of Song Boudoir embroidery, especially good at ancient masterpieces and history scroll works. Therefore, the main performance form of Bian embroidery was embroidery painting, mostly were appreciative works, practical products accounted for a smaller proportion, the work forms include seat screen, hanging embroidery, fan, decorative painting, photo portraits and so on.

\section{A. Kaifeng Embroidered Traditional Embroidery Painting}

The combination of Bian embroidery and historical painting is because this was an uncuttable history blood and also it was the inextricably story which combined under the historical and cultural city. On the basis of Tang Dynasty's religious decoration embroidery, Song Dynasty embroidered gradually shift to copy embroidery of ancient celebrity calligraphy and painting, and strive to be the same as the original, focus on realistic. A higher level is a kind of embroidery painting with the representative called "boudoir embroidery". Production of embroidery painting not only 
requires good embroidery skills, but also requires certain painting knowledge and cultural awareness, she should be able to understand the screen shaping, color, artistically style. The one who has these artistic accomplishment, often only the lady from noble family, they read poetry, good at painting and suffered full of artistic influence, so their embroidery paintings were very high-leveled, thus embroidery paintings in Song Dynasty called "boudoir embroidery." During Emperor Song Huizong time, embroidery painting specialist was set up and it was classified as landscapes, pavilions, figures, birds, and thus the famous embroidered craftsmen appeared continuously which made embroidery painting development to the highest level, and it developed from practical to art appreciation, brought painting into embroidery and formed unique ornamental embroidery.

Traditional design of Bian embroidery painting not only need to consider the painting effect, but also need to consider the entire process of embroidery craft, the use of materials and the stitches skill. It was not only manifested in the personality of painting, but also reflected in the material selection and needlework application because the art of embroidery is not only art of visual, but also the art of needle and thread. The design of different styles of embroidery drawings all had a large premise which is the need to understand the process, and carried out a careful planning to the work to be implemented. The plan includes what stitch technology the designed drawings suitable for, how to choose the base material, how to choose and match the thread, how to use the screen space to achieve the purpose of labor, material and time saving. As double-sided embroidery of Bian embroidery, since the base material uses a very thin texture silk yarn, polyester silk yarn and nylon yarn silk and other materials, as if embroider through the air, so it more suitable to perform the space, water, sky, cloud, tulle and other phenomena. Therefore when design these kinds of drawings, the composition should fully reflect the feeling of exquisitely carved, and cleverly use the virtualreal comparison relationship between the blank space and the embroidered space, painting screen generally will not be too full. In the selection of subject matter, Bian embroidery prefers to use images which can perform the transparency or sense of space. In the selection of embroidery stitch, Bian embroidery should cooperate with painting techniques such as flowers, birds, people and other subjects are suitable with Ping Xiufa and mainly use San Taozhen and Shizhen and pay attention to hide the stitches. And Luan Zhenxiu of Bian embroidery more suitable to express the brushwork or landscape of oil painting, fruit, still life like flowers, large portrait painting, abstract painting and so on. Most artists with quite adept skills, experience and imagination intentionally pursue a purely and aesthetic art effect of and create a lot of embroidery works.

\section{B. Modern Decorative Painting Embroidery of Bian Embroidery}

The traditional appreciative embroidery works from Bian embroidery generally without departing from the realistic mode. The past painting embroidery or art embroidered attached to painting, from traditional Chinese painting to oil painting, watercolor painting, photography, summed up they all belong to documentary painting. The modern decorative painting of Bian embroidery is completely different with realistic painting style. Decorative painting itself more emphasis on decorative, allegorical, symbolic, many images have been greatly exaggerated or simplified or induction treatment, the color performance also with obvious symbolic meaning and generality, many artificial factors been added in order to better reflect the artist's personal style and ideas. Decorative painting in some ways has more general, more concise, and more symbolic significance than realistic painting. The subject of Bian embroidery decorative painting still covered all things in the nature which including human as the major content, just in the composition, shape and expression form, it needs to emphasize decorative and sense of form, emphasize summarization, exaggeration and abstract.

\section{The Product Form of Bian Embroidery}

Bian embroidery as one of five famous Chinese embroideries, has been combined with the paintings in Northern Song Dynasty, the selected subjects mainly include well-known ancient masterpiece and historical scrolls. There are also subjects like calligraphy, landscape, flowers and birds, attic, figures and other classical themes. The Embroidery is elegant, delicate, simple with rich expressive content, in a variety of alternate stitches changes, so that Bian embroidery mainly are appreciation works, practical works accounted for a smaller proportion, the work forms include seat screen, hanging embroidery, fan-shaped embroidery, decorative painting, portraits and so on. From the view of product form, the form of Bian embroidery and Su embroidery summarized as appreciation type, but Yue embroidery and Xiang embroidery products are practical works.

The subjects of Bian embroidery mainly are ancient and famous paintings, they are the reflection of painting art. Use line as painting brush, the accumulation of silk and thread formed the embroidery, the craft is excellent. Different stitch has different visual presentation, bring people of different feelings, formed different product forms of Bian embroidery. Today's Bian embroidery through the accumulation and integration of other kinds of embroidery techniques, create the other two kinds of embroidery techniques, double-sided embroidery and double-sided with different pattern embroidery.

\section{COMPARISON WITH OTHER KINDS OF EMBROIDERY FROM EMBROIDERY FEATURES}

In the history of Chinese embroidery, Su embroidery is known as its exquisite, Shu embroidery is known as its gorgeous, Xiang embroidery is known as its practical. Their fames are bigger than Bian embroidery, but Bian embroidery is known as its specialty of ancient paintings, "Qingming Shanghe Tu - Hongqiao" is the masterpiece, and therefore it has a place in the various embroideries. Bian embroidery inherits the subjects and process characteristic of Song embroidery, absorbs the local flavor of Henan folk embroidery, Bian embroidery has Mengzhen xiu, Dazi xiu, Taozhen xiu, Qiangzhen xiu, Luanzhen xian, double-sided embroidery and double-sided with different pattern more than 30 kinds of embroidery stitches and embroidery species. It has delicate features of four famous embroideries, and also has unique rough geographical characteristics of central Plain. Since the 
Bian embroidery suffered more influence from Northern Song Dynasty embroidery so in style it was close to the painting's craft features. Its historical background has more advantages than the four embroideries, features of Bian embroidery works tend to be more elegant, dignified with rigorous composition and the overall sense, pursue the artistic conception and charm in Chinese painting and calligraphy with exquisite and delicate embroidery crafts, it is not difficult to see that the far-reaching historical and cultural influence on artistic style.

Bian embroidery is an exotic flower left from ancient culture. Its stitches active, jumpy and doesn't stick at trifles, shows the simple and magnanimous of Henan people who raised by this Central Plains. Although the classic and carefree of Bian embroidery and the quiet and elegant of Su embroidery contrast charmingly with each other, and no one can replace the other, but Bian embroidery fame is quite small. At present Bian embroidery researchers are too little, there are very few master craftsmen and very few of excellent Bian embroidery. The social frame of Bian embroidery can not compare with $\mathrm{Su}$ embroidery. How do make better heritage of Bian embroidery and how to improve its fame are worth serious thought.

\section{HERITAGE AND REgENERATION OF BIAN EMBROIDERY}

Today, in a sense, large-scale industrial machine production and advanced high-tech science and technology improvement, Bian embroidery as an old craft with complicated process and long time increasingly unable to meet the needs of today's society and market. Bian embroidery has a brilliant yesterday, but technological revolution and human ideas' change which brought by the social development, now it is in the recession state, almost on the verge of extinction, which is worrying. I believe the causes of this situation are as the following:

- The current measures for the traditional culture are not enough, neither the authorities effectively exercise its coordination function, fight against fake and shoddy behavior, rectify and standardize the market order, nor give Bian embroidery this Kaifeng's unique tradition process with sufficient attention and support, did not support for research of Bian embroidery, but mostly hold a more laissez-faire attitude, promotional efforts is not enough. In Kaifeng, Bian embroidery has a certain brand image, but not known in the country.

- Personnel aging troubled the development of Bian embroidery. Lack of training of Bian embroidery professionals without successors, high-skilled craftsmen decreased year by year with a serious brain drain.

- The quick impetuous mentality result the lack of traditional Bian embroidery fine works and social reputation decline. The production of traditional Bian embroidery fine works is a complex process, and some of the Bian embroidery production factories or family workshops use Bian embroidery banner seek nothing bu profits, a embroidery which need two months to complete only takes two or three days to rush out,in this way the embroidery will loss the characteristics of Bian embroidery, without its taste and style, actually it does not inherit the fine traditions of Bian embroidery.

To regain its past style of Bian embroidery and expose the grace which not inferior to $\mathrm{Su}$ embroidery, there are many works to be done:

- Establish a special fund, to conduct key support. Establish Bian embroidery museum to collect and display the provincial masterpiece of Bian embroidery. Museum can exhibit the development history of Bian embroidery and the masterpieces of Bian embroidery, also it selects high-skilled embroidery craftsmen for work performances, so domestic and foreign tourists can participate in embroidery production on-site and experience the embroidery making process, enjoy the fun of embroidery and so on.

- Establish the training mechanism for Bian embroidery reserve talents. For those who want to open Bian embroidery school, the state should allocate certain funds, reduce or eliminate tuition, develop employment policies in order to make Bian embroidery been inherited and developed, efforts to change the low cultural quality and low art appreciation level of existing employees.

- Innovation and creativity are the soul of any product design, we need to change our way of thinking, but also need the concept innovation and product reformation of Bian embroidery. For example Bian embroidery is added into high-grade commodity and high-grade wedding dress in order to seek different and authentic craftsmanship. Bian embroidery gifts and souvenirs not only have distinct geographical and cultural characteristics, but also combined with fashion culture organically with small size, light weight, exquisite production and unique package. While ensuring gradual production expansion of Bian embroidery crafts, we also need to design middle and low-end products which are required by mass-market of general tourist at the same time. It also produced low-end Bian embroidery products with novelty design, sophisticated production, quality packaging and low price, easy to carry, in ornamental and practical combination, to make foreign products out of the market gradually.

- Learn and study the approaches from abroad which protect and inherit the traditional arts and crafts. There are many contemporary developed countries have set out to restore and study traditional arts and crafts at a high level, such as many Japanese arts and crafts workshops still exist in the most original ecological way under government's care and support, a number of research institutions and scholars which funded by the Government engaged in the research of traditional crafts and rescuing conservation.

- In addition, Bian embroidery industry needs common support from all aspects. Cultural authorities should pay attention to attract capital injection and development of exporting products within and outside the province. Technology mature and update will also bring a 
broader develop space and develop opportunities to Bian embroidery, European and American countries have been a great yearning for China's embroidery, in cooperation with the foreign brands will enhance the international visibility of Bian embroidery. We respect history, but it can not be shelved. Participating in the competition and seeking for development are the right attitude to carry forward the national culture.

Undoubtedly, the fundamental way out of Bian embroidery should be solved by the market itself. Its fundamental problem is that it is always a hand-embroidery which can not be produced by big industrialization ; tradition, technology, a lot of labor force, product innovation to meet the market demand and consumer aesthetics, all of these constitute the lifeline for continued survive and development of traditional crafts. The charm of Bian embroidery is handmade; conversely, the long and arduous journey of handicrafts also restricted the industrialization, large-scale development of embroidery. This contradiction of tradition and modern conflict is sufficient to cause people to ponder: How to release Bian embroidery's new image, new technology, new connotation based on the tradition in order to meet the needs of the modern people, modern family and modern aesthetic, and it is an important issue handed by the history.

\section{REFERENCES}

[1] Tian Zibing. China's craft art history, Oriental Publishing Center, 1996 edition.

[2] Li Youyou. Folk embroidery, China Light Industry Press, 2005.

[3] Wang Binghua. Archaeological research on Silk Road, Xinjiang People's Publishing Company, 1993 edition.

[4] Chen Li. Embroidery art design tutorials, Tsinghua University Press, 2005 edition. 